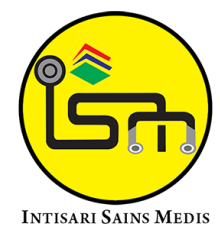

Published by Intisari Sains Medis

\title{
Peran HbA1c dalam progresi dan prognosis COVID-19 pada pasien diabetes mellitus
}

'Fakultas Kedokteran, Universitas Udayana, Bali, Indonesia

${ }^{2}$ Rumah Sakit Bhayangkara, Denpasar, Bali, Indonesia

\section{*Korespondensi:}

Kadek Wisnu Segara Karya;

Rumah Sakit Bhayangkara, Denpasar, Bali, Indonesia. wisnuverbind@gmail.com

Ni Luh Parameswari Praptika ${ }^{1}$, Kadek Wisnu Segara Karya ${ }^{2 *}$

\section{ABSTRACT}

Objective: This systematic review determined the role of $\mathrm{HbA1C}$ in the progression and prognosis of COVID-19 in patients with diabetes mellitus from several previously published articles.

Method: We searched from an open-access database according to the PRISMA (Preferred Reporting Items for Systematic Reviews and Meta-Analyses) guidelines and the PICO criteria. The inclusion criteria for the article search included: 1) COVID-19 patients with diabetes mellitus; 2) full articles; 3) English articles; 4) article publication time range from 2016 to 2021. Quality assessment for each article is evaluated using a checklist from Strengthening the Reporting of Observational Studies in Epidemiology (STROBE).

Result: We obtained two cohort studies and four cross-sectional studies of all the articles reviewed from 2019-2021. All studies evaluated the role of HbA1C in the progression, prognosis, and mortality of COVID-19 patients with diabetes mellitus. Most of the reported studies showed an association between elevated $\mathrm{HbA1C}$ and worsening of the COVID-19 disease prognosis. The association was assessed by the patient's clinical deterioration included lower oxygen saturation, increased NLR (neutrophil-lymphocyte ratio), the tendency to lymphopenia, improved renal function, increased ICU admission, and mechanical ventilation and increased ventilation mortality.

Conclusion: A high $\mathrm{HbA1c}$ was closely related to a worse COVID-19 prognosis in clinical development and mortality. We found the potential for developing a scoring system to predict the worsening and mortality of COVID-19 and improve the quality of prevention and management of COVID-19, especially in patients with diabetes mellitus.

Keywords: COVID-19 prognosis, HbA1C, diabetes mellitus, mortality

Cite This Article: Praptika, N.L.P., Karya, K.W.S. 2021. Peran HbA1c dalam progresi dan prognosis COVID-19 pada pasien diabetes mellitus. Intisari Sains Medis 12(3): 682-688. D0l: 10.15562/ism.v12i3.1113

\section{ABSTRAK}

Tujuan: mengkaji peran HbA1c dalam progresi dan prognosis COVID-19 pada pasien diabetes mellitus dari beberapa literatur yang telah dipublikasi sebelumnya.

Metode: Pencarian literatur secara sistematis dilakukan pada basis data dengan akses terbuka sesuai dengan pedoman PRISMA (Preferred Reporting Items for Systematic Reviews and Meta-Analyses) dan kriteria PICO. Kriteria inklusi pencarian artikel antara lain: 1) pasien COVID-19 dengan diabetes mellitus; 2) artikel lengkap; 3) artikel berbahasa Inggris; 4) rentang waktu terbit artikel dari tahun 2016 hingga tahun 2021. Penilaian kualitas pada setiap artikel yang dievaluasi menggunakan checklist dari Strengthening the Reporting of Observational Studies in Epidemiology (STROBE).

Hasil: Dari seluruh artikel yang dikaji dari tahun 20192021, didapatkan 2 studi kohort dan 4 studi potong lintang. Keseluruhan studi mengevaluasi peran $\mathrm{HbA1C}$ dalam progresi, prognosis, maupun mortalitas pada pasien COVID-19 dengan diabetes mellitus. Sebagian besar penelitian yang dilaporkan menunjukkan keterkaitan antara peningkatan $\mathrm{HbA1c}$ dan perburukan prognosis penyakit COVID-19 yang dinilai dari perburukan klinis pasien yaitu saturasi oksigen yang lebih rendah, meningkatnya NLR (neutrophil lymphocyte ratio), kecenderungan limfopenia, fungsi ginjal yang meningkat, peningkatan admisi ICU dan pemanfaatan ventilator mekanik serta meningkatnya mortalitas.

Simpulan: HbA1c yang tinggi terbukti berhubungan erat dengan prognosis COVID-19 yang lebih buruk ditinjau dari perkembangan klinis hingga tingkat mortalitas yang terjadi. Hal ini menunjukkan potensi berkembangnya sistem skoring untuk memprediksi perburukan dan mortalitas COVID-19 serta peningkatan kualitas pencegahan dan tatalaksana COVID-19 terutama pada pasien diabetes mellitus. 


\section{PENDAHULUAN}

Sejak kasus pertama di Cina pada Desember 2019, wabah penyakit coronavirus-2019 (COVID-19), dengan cepat menyebar ke seluruh dunia dan dideklarasikan sebagai pandemi oleh World Health Organization (WHO) pada 11 Maret 2020., Patogen penyakit tersebut diidentifikasi sebagai virus coronavirus-2 (SARS-CoV-2) yang sangat menular dan dapat menyerang tubuh manusia melalui Angiotensin converting enzyme-2 (ACE-2). ${ }^{3}$ Manifestasi klinis COVID-19 berupa demam, batuk, dispnea, mialgia, kelelahan. Kasus yang parah dapat dengan cepat berkembang menjadi sindrom gangguan pernapasan akut, syok septik, dan kegagalan multiorgan. ${ }^{4}$ Tingkat kematian COVID-19 dipengaruhi oleh banyak faktor seperti usia, penyakit penyerta termasuk diabetes mellitus, hipertensi, kardiovaskular, dan penyakit serebrovaskular, serta ketersediaan sumber daya medis. Tingkat kematian juga sangat bervariasi baik di berbagai negara maupun pada periode wabah yang berbeda. Tingkat kematian yang dilaporkan untuk pasien rawat inap dengan COVID-19 berkisar antara 1,4\% hingga $22,5 \%$, yang perbedaan angka ini disebabkan oleh karakteristik populasi pasien yang berbeda., ${ }^{2,5}$

Penelitian terbaru menunjukkan bahwa diabetes mellitus (DM) merupakan salah satu penyakit komorbid yang paling umum ditemukan pada pasien COVID-19, dengan prevalensi berkisar antara 5,3\% hingga 58,0\%. ${ }^{1,6,7}$ Diabetes telah dikaitkan dengan peningkatan mortalitas pada epidemi virus sebelumnya, seperti wabah SARS-CoV-1 dan Middle East Respiratory Syndrome Coronavirus (MERS CoV). ${ }^{8,9}$ Hasil serupa juga dilaporkan pada pandemi COVID-19, beberapa penelitian menunjukkan bahwa diabetes mellitus adalah faktor risiko dalam perburukan prognosis COVID-19. ${ }^{6,10,11}$ Sebuah artikel meta-analisis menunjukkan bahwa diabetes mellitus dikaitkan dengan risiko untuk masuk ICU lebih dari dua kali lipat dibandingkan dengan pasien COVID-19 tanpa komorbid diabetes mellitus. ${ }^{12}$

Kontrol glikemik yang tidak adekuat (hiperglikemia) terutama disebabkan oleh rendahnya kesadaran akan pentingnya kontrol diabetes mellitus, yang merupakan penyakit non-infeksi kronis dengan angka morbiditas yang tinggi, yaitu sekitar setengah miliar pengidap di seluruh dunia. ${ }^{13}$ Banyak penelitian membuktikan bahwa hiperglikemia dapat mempengaruhi respon imun seluler, meningkatkan morbiditas dan mortalitas terkait infeksi. ${ }^{14,15} \mathrm{HbA} 1 \mathrm{c}$ dianggap sebagai standar baku emas untuk mengevaluasi dan memberikan nilai rata-rata kadar glukosa darah selama tiga bulan terakhir. Kadar HbAlc yang tinggi terkait dengan risiko komplikasi pada pasien diabetes. ${ }^{16}$ Studi ini bertujuan untuk mengkaji peran HbAlc dalam progresi dan prognosis COVID-19 pada pasien diabetes mellitus dari beberapa literatur yang telah dipublikasi sebelumnya.

\section{METODE}

Pencarian literatur secara sistematis dilakukan sesuai dengan pedoman PRISMA (Preferred Reporting Items for Systematic Reviews and Meta-Analyses) untuk meningkatkan kelengkapan dan transparansi pelaporan. Pencarian menggunakan kriteria PICO, Patient (P): pasien COVID-19 dengan diabetes mellitus. Indication (I): level HbAlc yang tinggi. Control (C): pasien COVID-19 dengan kadar HbAlc normal/rendah. Outcome (O): evaluasi peran HbA1c dalam progresi dan prognosis COVID-19 (Gambar 1). Batasan pencarian hanya pada artikel dengan waktu publikasi dari tahun 2016 hingga tahun 2021 yang
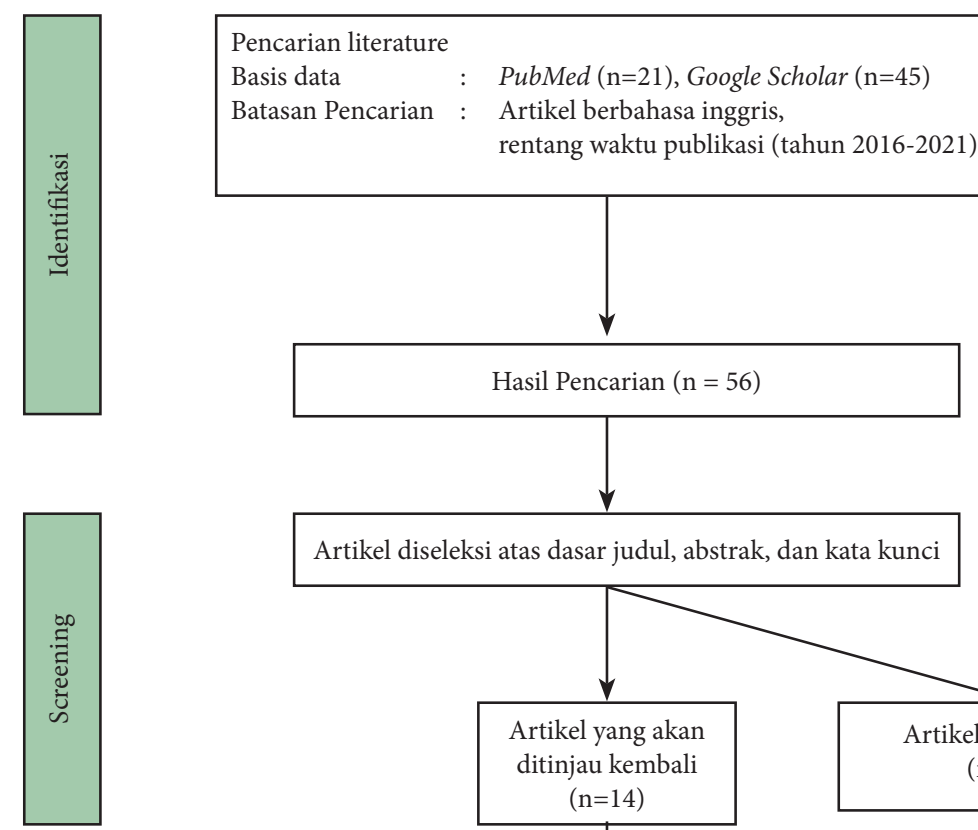

Hasil Pencarian $(\mathrm{n}=56)$

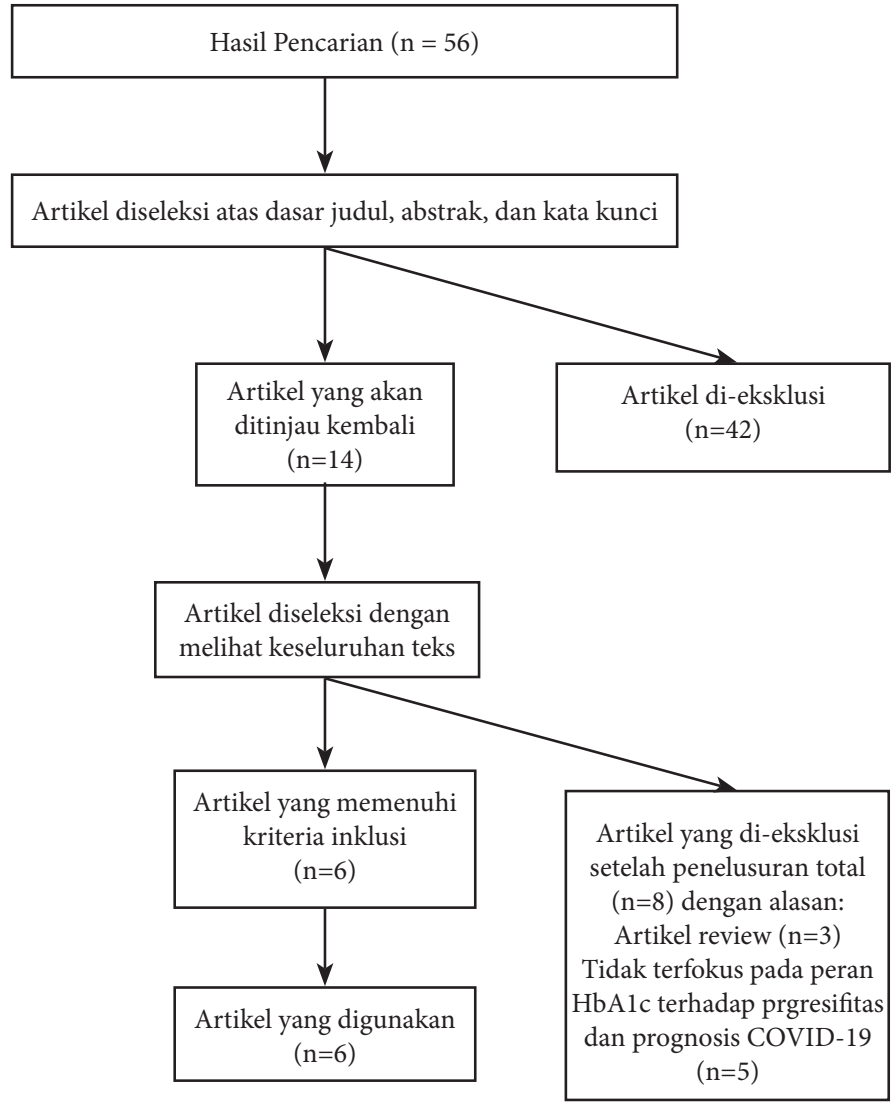

Gambar 1. Bagan alur seleksi artikel dengan pedoman PRISMA 
berfokus pada topik peran $\mathrm{HbAlc}$ dalam progresi dan prognosis COVID-19.

Kriteria inklusi pencarian artikel antara lain: 1) pasien COVID-19 dengan diabetes mellitus; 2) artikel lengkap; 3) artikel berbahasa Inggris; 4) rentang waktu terbit artikel dari tahun 2016 hingga tahun 2021. Kriteria eksklusi dari kajian literatur sistematis ini adalah semua artikel yang tidak memenuhi salah satu kriteria inklusi. Penilaian kualitas pada setiap artikel yang dievaluasi menggunakan checklist dari Strengthening the Reporting of Observational Studies in Epidemiology (STROBE) (Tabel 1). Lingkaran hijau menjelaskan kriteria tersebut terpenuhi, lingkaran kuning mempresentasikan bahwa kriteria tersebut tidak dibahas secara lengkap dan rinci, serta lingkaran merah berarti poin tersebut tidak dijelaskan. Suatu artikel memiliki lingkaran hijau semakin banyak, berarti semakin banyak kriteria STROBE yang terpenuhi, sehingga artikel tersebut memiliki kualitas baik. Namun, bila lingkaran merah lebih banyak, tentunya artikel tersebut memiliki kualitas yang buruk.

\section{Strategi Pencarian Literatur}

Penelusuran literatur dalam kajian sistematis menggunakan database Pubmed dan Google Scholar pada 20 Mei 2021 dengan bahasa Inggris. Strategi pencarian artikel pada kajian literatur sistematis ini antara lain dengan mengidentifikasi kata kunci yang relevan terhadap topik, selanjutnya dilakukan identifikasi kemungkinan sinonim yang berkaitan dengan kata kunci. langkah berikutnya dilakukan penelusuran dengan metode boolean operator untuk mendapatkan hasil yang spesifik dan sesuai topik. Kata kunci serta boolean operator yang digunakan pada kajian ini adalah (("HbA1c" OR "Hemoglobin Alc") OR "glycosylated hemoglobin")) AND (("COVID-19 prognosis") OR "Coronavirus diseases-19 prognosis") OR "Coronavirus prognosis")) OR (("COVID-19 progressions") OR "Coronavirus diseases-19 progressions") OR "Coronavirus progressions")). Selanjutnya dilakukan pembatasan terhadap bahasa, topik, dan tahun. Kemudian mengevaluasi setiap artikel yang diperoleh sesuai kriteria inklusi yang telah ditetapkan.

\section{Seleksi Literatur}

Setelah penelusuran dengan kata kunci serta pembatasan rentang waktu yang telah ditentukan, pada kedua database ditemukan artikel dengan jumlah yang berbeda. Proses seleksi awal dilakukan dengan mengidentifikasi kesesuaian judul, abstrak serta kata kunci dengan topik kajian. Pada setiap artikel yang tidak dapat diakses serta tidak memenuhi kriteria inklusi segera di eksklusi. Artikel yang telah masuk ke kriteria inklusi akan dilakukan identifikasi menggunakan pendekatan PICO, jurnal yang tidak sesuai akan segera di eksklusi. Jurnal akan ditinjau satu per satu dengan melihat metode, hasil, diskusi serta pembahasan. Langkah berikutnya dilakukan telaah pada seluruh bagian artikel untuk dijadikan dasar studi dalam kajian literatur sistematis ini.

\section{Pengumpulan Data}

Seluruh artikel yang telah diseleksi akan dilakukan ekstraksi data dengan mengidentifikasi keseluruhan artikel secara independen. Informasi yang diperoleh akan dikumpulkan menggunakan Microsoft Excel agar mempermudah dalam proses analisis. Data yang dikumpulkan antara lain nama penulis utama, negara, tahun terbit, metode penelitian, jumlah keseluruhan subjek yang terlibat dalam penelitian jumlah subjek dengan diabetes, kadar HbAlc, hubungan variabel yang dicari, serta hasil temuan,. Pada setiap artikel juga dilakukan telaah kritis untuk menilai kualitas artikel. Jenis data yang digunakan dalam kajian sistematis berupa data kuantitatif serta kualitatif yang diperoleh dengan mengidentifikasi peran $\mathrm{HbAlc}$ dalam progresi dan prognosis COVID-19.

\section{HASIL}

\section{Seleksi Literatur}

Seluruh artikel yang digunakan pada kajian sistematis ini dipublikasi dari tahun 2019 hingga tahun 2021. Jenis studi yang digunakan yaitu dua artikel dengan metode kohort dan empat artikel merupakan studi cross-sectional. Mayoritas studi dilakukan di Cina, hanya satu studi yang dilakukan di Perancis. Seluruh studi memiliki jumlah subyek penelitian lebih dari 50 pasien COVID-19 (Tabel 1).
Keseluruhan studi mengevaluasi peran HbA1c dalam progresi, prognosis, maupun mortalitas pada pasien COVID-19 dengan diabetes mellitus. Dari ke-enam artikel yang terlibat, hanya penelitian dari Cariou B et al. yang menunjukkan tidak adanya hubungan yang signifikan antara $\mathrm{HbAlc}$ dengan peningkatan risiko mortalitas pasien COVID-19. Pada studi ini nilai OR untuk kadar HbAlc $\geq 9,0 \%$ adalah $0,78(95 \%$ CI 1,$32 ; 25,53) \mathrm{p}=0,02$, hasil ini menunjukkan bahwa HbAlc tidak berperan dalam progresi penyakit COVID-19.

Pada penelitian kohort Liu Z et al., melaporkan hubungan yang signifikan antara $\mathrm{HbAlc}$ dengan progresi penyakit, yang dilihat dari keperluan ICU dan angka kematian pasien selama perawatan di rumah sakit. Hasil yang sama juga ditemukan pada penelitian cross-sectional oleh Liu Y et al., dimana kadar HbA1c yang tinggi ( $\geq 6,5 \%$ ) yang dievaluasi saat masuk rumah sakit berhubungan signifikan terhadap mortalitas penyakit COVID-19 (95\% CI 1,16; 2.15), $\mathrm{p}=0,004$. Sedangkan penelitian Liu L et al., menyatakan bahwa tiap peningkatan kadar HbAlc sebanyak $1 \%$ berhubungan secara signifikan dengan mortalitas penyakit COVID-19, dengan hazard ratio $1,58(95 \%$ CI 1,16;2,15), $\mathrm{p}=$ 0,004 .

Penelitian Wang $\mathrm{Z}$ et al., menemukan peran HbAlc dalam peningkatan mortalitas, berkorelasi positif terhadap hiperkoagulasi, serta berkorelasi negatif dengan saturasi oksigen pasien COVID-19. Sedangkan Lu X et al., mengevaluasi peran HbAlc dalam perburukan prognosis klinis melalui gambaran CT-scan paruparu. Penelitian ini menemukan bahwa kadar HbAlc dapat berperan sebagai prediktor keparahan gambaran radiografi pasien COVID-19.

\section{Risiko Bias}

Evaluasi kualitas pada ke-enam artikel yang digunakan pada tinjauan sistematik ini berpedoman pada STROBE Checklist. Pada keseluruhan artikel yang digunakan, semuanya memiliki kualitas yang baik, berdasarkan lingkaran hijau yang mendominasi pada penilaian dengan STROBE Checklist (Gambar 2). 


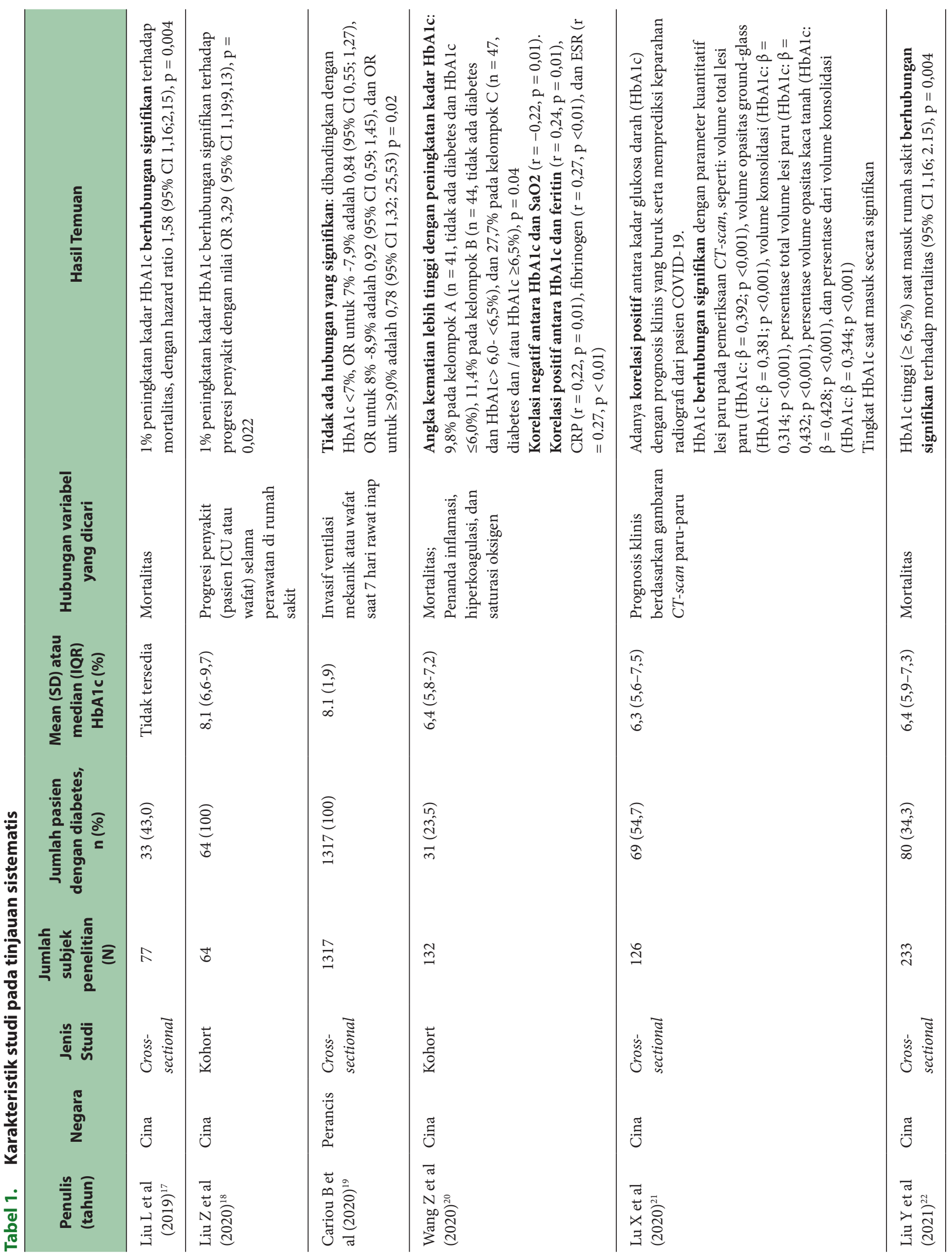




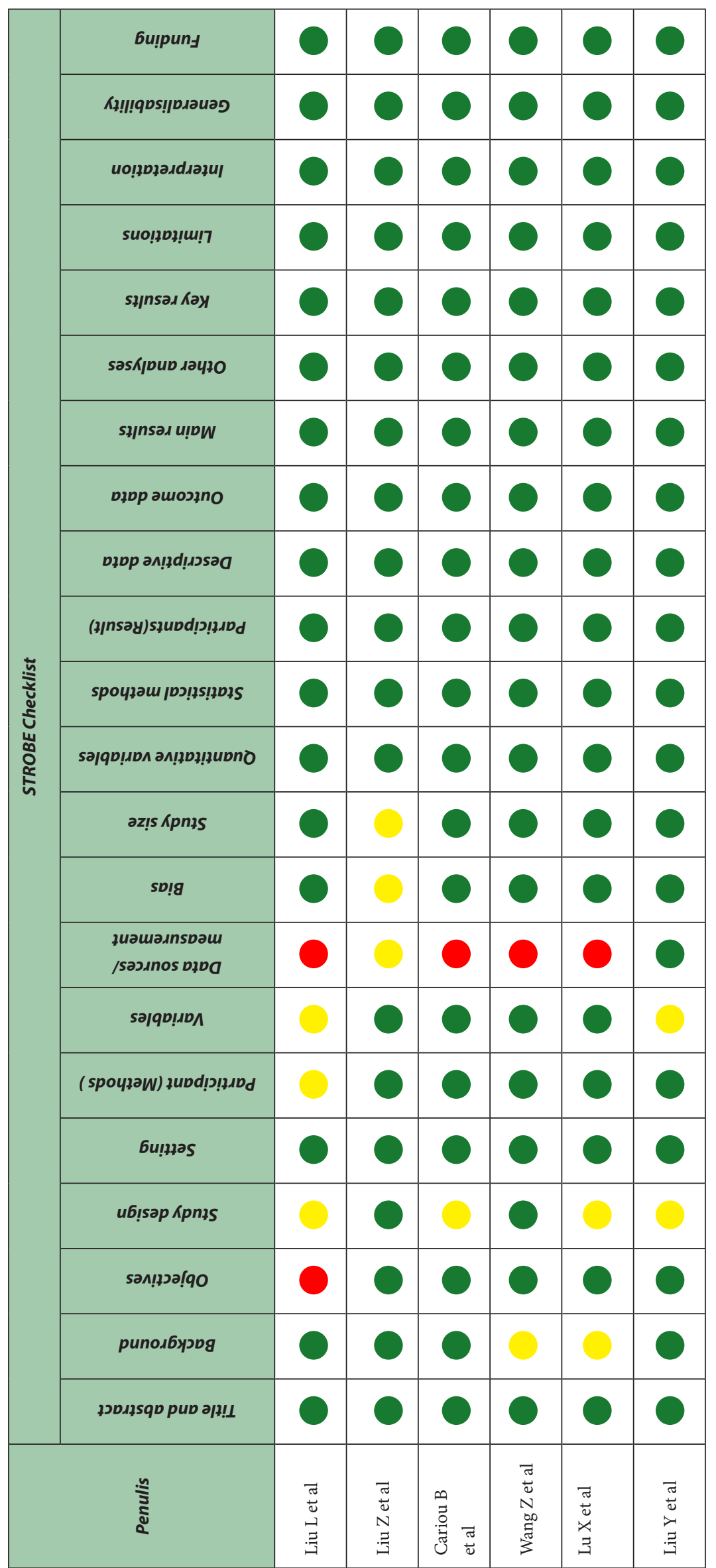

\section{DISKUSI}

Tinjauan sistematik ini terdiri dari empat studi potong lintang dan dua studi kohort yang menganalisis hubungan $\mathrm{HbAlc}$ dengan prognosis COVID-19. Lima dari studi menyatakan adanya hubungan antara HbA1c dengan prognosis COVID-19 yang dinilai baik dari perburukan klinis pasien, laboratorium dan CT-scan, penggunaan ventilasi mekanik atau tingkat perawatan ICU, dan tingkat mortalitas. Secara keseluruhan, peningkatan $\mathrm{HbA} 1 \mathrm{c}$ sebanyak $1 \%$ dan nilai $\mathrm{HbA1c} \geq 6,5 \%$ baik dengan atau tanpa riwayat diabetes sebelumnya berhubungan signifikan dengan perburukan penyakit yang lebih parah.

Peningkatan HbAlc berhubungan dengan klinis pasien COVID-19 yang lebih buruk. Hal ini jelas terlihat pada penelitian Liu L et al dan Wang $\mathrm{Z}$ et al. yang menunjukkan signifikansi hubungan antara peningkatan $\mathrm{HbAlc}$ dengan perburukan saturasi oksigen dan peningkatan detak jantung pasien. Selain itu, Liu Z et al juga menunjukkan bahwa pasien COVID-19 tanpa diabetes lebih sering menunjukkan klinis demam dibandingkan mereka yang dengan diabetes. ${ }^{17,18}$ Hal ini terjadi karena adanya penurunan imunitas tubuh dan respon interferon yang rendah akibat kontrol glikemik insufisien sehingga berbagai macam infeksi oportunis dapat terjadi. Penurunan saturasi oksigen yang lebih buruk pada pasien COVID-19 dengan diabetes juga diduga akibat banyaknya hemoglobin terglikosilasi sehingga menjadi target mudah bagi virus untuk melanjutkan replikasi secara agresif. ${ }^{23}$

Terkait dengan pemeriksaan penunjang, pasien dengan $\mathrm{HbAlc}$ yang tinggi menunjukkan parameter inflamasi yang lebih tinggi, fungsi ginjal dan kekentalan darah yang meningkat. Hal ini menunjukkan bahwa peningkatan HbAlc dapat berperan sebagai indikator status glikemik jangka panjang yang menunjukkan prognosis pasien COVID-19. Peningkatan HbAlc yang diiringi proses inflamasi yang lebih progresif dan kekentalan darah yang lebih tinggi berisiko pada berbagai macam infeksi yang dapat menyebabkan sepsis dan kegagalan organ multipel. ${ }^{18-21}$

Proses inflamasi progresif ini juga 
tercermin melalui pemeriksaan CT-scan paruyangmenunjukkanlesiparuyanglebih parah. Mekanisme patologis mengenai hubungan positif antara keparahan lesi paru dan kadar glukosa darah pada pasien COVID-19 masih belum jelas. Tingginya kadar glukosa darah dapat meningkatkan replikasi virus dan menekan respon imun antivirus. ${ }^{24,25}$ Selain itu, pasien DM lebih cenderung kekurangan gizi dan rentan untuk mengembangkan badai sitokin, yang pada akhirnya dapat menyebabkan kerusakan yang cepat, dibandingkan pasien non-DM. ${ }^{20}$ Selebihnya, disfungsi paru yang mempengaruhi volume paru, kapasitas difusi paru, pernapasan, tonus bronkomotor, dan persarafan bronkus neuroadrenergik pada pasien nonCOVID-19 dengan DM telah dilaporkan sebelumnya. ${ }^{26}$ Semua faktor ini dapat menjelaskan kecenderungan kerusakan paru yang lebih serius pada pasien COVID-19 diabetes dengan glukosa darah yang tidak terkontrol. Keparahan klinis dan parameter penunjang sejalan dengan peningkatan penggunaan ruang ICU dan angka mortalitas COVID-19. ${ }^{20,21} \mathrm{Hal}$ ini mengindikasikan pentingnya skrining diabetes atau hiperglikemia pada pasien COVID-19 untuk menghindari terjadinya underdiagnosis, mengingat riwayat diabetes biasanya hanya berdasarkan pada anamnesis.

Kemungkinan mekanisme COVID-19 yang menyebabkan metabolisme glukosa abnormal termasuk kerusakan sel beta pankreas dan resistensi insulin. Penelitian sebelumnya telah melaporkan bahwa beberapa virus dapat secara langsung menyebabkan kerusakan sel beta pankreas, ${ }^{27,28}$ dan angiotensin converting enzyme-2 (ACE2) sebagai reseptor SARSCoV-2 memiliki ekspresi yang lebih tinggi di jaringan endokrin pankreas daripada di jaringan eksokrin. ${ }^{23}$ Otopsi menunjukkan bahwa meskipun sejumlah kecil sel beta pankreas mengalami degenerasi di jaringan pankreas, sementara analisis imunohistokimia dan tes reaksi berantai polimerase tidak mendeteksi keberadaan SARS-CoV-2 pada sel beta pankreas, ${ }^{29}$ sehingga menunjukkan bahwa tidak ada cukup bukti akan kerusakan langsung yang disebabkan oleh SARS-CoV-2. Tingkat plasminogen activator inhibitor-1, CRP, serum amyloid A, TNF- $\alpha$, IL- $1 \beta$, dan
IL-6 telah terbukti meningkat pada pasien obesitas dan diabetes mellitus tipe 2. IL$1 \beta$ dapat menyebabkan disfungsi sel beta pankreas dan apoptosis, dan tingkat faktor ini dapat dikurangi dengan modifikasi gaya hidup dan penurunan berat badan, yang menunjukkan bahwa penanda inflamasi mungkin terlibat dalam kerusakan sel beta pankreas dan resistensi insulin. ${ }^{30}$ Faktor inflamasi yang dilepaskan sebagai respons terhadap SARS-CoV-2 mungkin juga terlibat dalam kerusakan sel beta pankreas dan resistensi insulin yang mengakibatkan gangguan metabolisme glukosa yang lebih parah pada saat infeksi terjadi.

\section{SIMPULAN}

Data yang tersedia menunjukkan hubungan linier $\mathrm{HbAlc}$ dengan prognosis COVID-19 dan peningkatan mortalitas terkait COVID-19 pada pasien DM dengan kontrol glikemik yang buruk sebelum infeksi. Studi prospektif tambahan diperlukan untuk sepenuhnya menetapkan korelasi antara kontrol glikemik dan prognosis COVID-19 pada pasien DMT2 atau hiperglikemik, bukti yang ada juga dapat digunakan sebagai basis tatalaksana hiperglikemia atau DM pada pasien COVID-19 dengan meningkatkan kontrol glikemik jangka panjang.

\section{KONTRIBUSI PENULIS}

Semua penulis memiliki porsi kontribusi yang sama dalam penulisan artikel ini.

\section{PENDANAAN}

Penulis tidak menerima bantuan dana dalam penulisan artikel ini.

\section{KONFLIK KEPENTINGAN}

Tidak terdapat konflik kepentingan dalam penulisan artikel ini, semua penulis telah memahami dan menyetujui manuskrip final.

\section{DAFTAR PUSTAKA}

1. Huang C, Wang Y, Li X, et al. Clinical features of patients infected with 2019 novel coronavirus in Wuhan, China. Lancet. 2020;395(10223):497506. doi:10.1016/s0140-6736(20)30183-5

2. Guan $\mathrm{W}, \mathrm{Ni} \mathrm{Z}$, $\mathrm{Hu} \mathrm{Y}$, et al. Clinical Characteristics of Coronavirus Disease 2019 in China. N Engl J Med. 2020;382(18):1708-1720. doi:10.1056/nejmoa2002032

3. Wu Z, McGoogan JM. Characteristics of and Important Lessons From the Coronavirus Disease 2019 (COVID-19) Outbreak in China. JAMA. 2020;323(13):1239. doi:10.1001/ jama.2020.2648

4. Chen N, Zhou M, Dong X, et al. Epidemiological and clinical characteristics of 99 cases of 2019 novel coronavirus pneumonia in Wuhan, China: a descriptive study. Lancet. 2020;395(10223):507-513. doi:10.1016/s01406736(20)30211-7

5. Wang $\mathrm{D}, \mathrm{HuB}, \mathrm{HuC}$, etal.ClinicalCharacteristics of 138 Hospitalized Patients With 2019 Novel Coronavirus-Infected Pneumonia in Wuhan, China. JAMA. 2020;323(11):1061. doi:10.1001/ jama.2020.1585

6. Zhou F, Yu T, Du R, et al. Clinical course and risk factors for mortality of adult inpatients with COVID-19 in Wuhan, China: a retrospective cohort study. Lancet. 2020;395(10229):10541062. doi:10.1016/s0140-6736(20)30566-3

7. Singh AK, Gupta R, Ghosh A, Misra A. Diabetes in COVID-19: Prevalence, pathophysiology, prognosis and practical considerations. Diabetes Metab Syndr Clin Res Rev. 2020;14(4):303-310. doi:10.1016/j.dsx.2020.04.004

8. Yang JK, Feng Y, Yuan MY, et al. Plasma glucose levels and diabetes are independent predictors for mortality and morbidity in patients with SARS. Diabet Med. 2006;23(6):623-628. doi:10.1111/j.1464-5491.2006.01861.x

9. Al-Tawfiq JA, Hinedi $\mathrm{K}$, Ghandour J, et al. Middle East Respiratory Syndrome Coronavirus: A Case-Control Study of Hospitalized Patients. Clin Infect Dis. 2014;59(2):160-165. doi:10.1093/cid/ciu226

10. Guo W, Li M, Dong Y, et al. Diabetes is a risk factor for the progression and prognosis of COVID -19. Diabetes Metab Res Rev. 2020;36(7). doi:10.1002/dmrr.3319

11. Huang R, Zhu L, Xue L, et al. Clinical findings of patients with coronavirus disease 2019 in Jiangsu province, China: A retrospective, multi-center study. PLoS Negl Trop Dis. 2020;14(5):e0008280. doi:10.1371/journal. pntd.0008280

12. Roncon L, Zuin M, Rigatelli G, Zuliani G. Diabetic patients with COVID-19 infection are at higher risk of ICU admission and poor shortterm outcome. J Clin Virol. 2020;127:104354. doi:10.1016/j.jcv.2020.104354

13. Maddaloni E, Buzzetti R. Covid-19 and diabetes mellitus: unveiling the interaction of two pandemics. Diabetes Metab Res Rev. 2020;36(7). doi:10.1002/dmrr.3321

14. Delamaire $M$, Maugendre D, Moreno $M$, Le Goff M-C, Allannic H, Genetet B. Impaired Leucocyte Functions in Diabetic Patients. Diabet Med. 1997;14(1):29-34. doi:10.1002/ (sici)1096-9136(199701)14:1<29::aiddia300>3.0.co;2-y

15. Shah BR, Hux JE. Quantifying the Risk of Infectious Diseases for People With Diabetes. Diabetes Care. 2003;26(2):510-513. doi:10.2337/ diacare. 26.2 .510

16. Nalysnyk L, Hernandez-Medina M, Krishnarajah G. Glycaemic variability and complications in patients with diabetes mellitus: evidence from a systematic review 
of the literature. Diabetes, Obes Metab. 2010;12(4):288-298. doi:10.1111/j.14631326.2009.01160.x

17. Liu L, Wei W, Yang K, et al. Glycemic control before admission is an important determinant of prognosis in patients with coronavirus disease 2019. J Diabetes Investig. Published online 2020:1-10. doi:10.1111/jdi.13431

18. Liu Z, Bai X, Han X, et al. The association of diabetes and the prognosis of COVID-19 patients: A retrospective study. Diabetes Res Clin Pract. 2020;169:108386. doi:10.1016/j. diabres.2020.108386

19. Cariou B, Hadjadj S, Wargny M, et al. Phenotypic characteristics and prognosis of inpatients with COVID-19 and diabetes: the CORONADO study. Diabetologia. 2020;63(8):1500-1515. doi:10.1007/s00125-020-05180-x

20. Wang Z, Du Z, Zhu F. Glycosylated hemoglobin is associated with systemic inflammation, hypercoagulability, and prognosis of COVID-19 patients. Diabetes Res Clin Pract. 2020;164:108214. doi:10.1016/j. diabres.2020.108214

21. Lu X, Cui Z, Pan F, et al. Glycemic status affects the severity of coronavirus disease 2019 in patients with diabetes mellitus: an observational study of CT radiological manifestations using an artificial intelligence algorithm. Acta Diabetol. 2021;58(5):575-586. doi:10.1007/ s00592-020-01654-x

22. Liu Y, Lu R, Wang J, et al. Diabetes, even newly defined by HbAlc testing, is associated with an increased risk of in-hospital death in adults with COVID-19. BMC Endocr Disord. 2021;21(1):110. doi:10.1186/s12902-021-00717-6

23. Yang JK, Lin SS, Ji XJ, Guo LM. Binding of SARS coronavirus to its receptor damages islets and causes acute diabetes. Acta diabetologica. 2010 Sep 1;47(3):193-9.

24. Kulcsar KA, Coleman CM, Beck SE, Frieman MB.Comorbid diabetes results in immune dysregulation and enhanced dis- ease severity following MERS-CoV infection. JCI Insight. 2019. https ://doi.org/10.1172/jci. insight. 131774

25. Philips BJ, Meguer JX, Redman J, Baker EH. Factors determining the appearance of glucose in upper and lower respiratory tract secretions. Intensive Care Med 2003;29(12):2204-2210. https://doi.org/10.1007/s00134-003-1961-2
26. Fuso L, Pitocco D, Antonelli-Incalzi R. Diabetic lung, an underrated complication from restrictive functional pattern to pulmonary hypertension. Diabetes Metab Res Rev 2009;35(6):e3159. https ://doi.org/10.1002/ dmrr.3159

27. Jaeckel E, Manns M, Von Herrath M. Viruses and diabetes. Ann N Y Acad Sci 2002;958:7-25.

28. Roivainen $M$, Rasilainen $S$, Ylipaasto $P$, et al. Mechanisms of coxsackievirus-induced damage to human pancreatic beta- cells. J Clin Endocrinol Metab 2000;85(1):432-40.

29. Yao XH, Li TY, He ZC, et al. A pathological report of three COVID-19 cases by minimally invasive autopsies. Zhonghua Bing Li Xue $\mathrm{Za}$ Zhi 2020;49:E009.

30. Emanuela F, Grazia M, Marco de R, Maria Paola L, Giorgio F, Marco B. Inflammation as a link between obesity and metabolic syndrome. J Nutr Metab 2012;2012 476380.

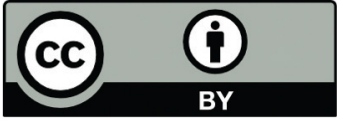

This work is licensed under a Creative Commons Attribution 